\title{
ASSOCIATION BETWEEN MURINE DOUBLE MINUTE 2 - T309G polymorphism and recurrence of hepatocellular carcinoma after surgical treatment
}

\author{
Uirá Fernandes TEIXEIRA ${ }^{1}$, Andréa Gomes Coelho IZAGUIRRE ${ }^{1}$, Mayara Christ MACHRY², \\ Carlos Thadeu CERSKI ${ }^{3}$, Ajácio Bandeira de Mello BRANDÃO ${ }^{1}$ \\ and Paulo Roberto Ott FONTES ${ }^{1}$
}

Received 30/5/2014

Accepted 4/8/2015

\begin{abstract}
Background - Discovery and incorporation of biomarker panels to cancer studies enabled the understanding of genetic variation and its interference in carcinogenesis at molecular level. The potential association between single nucleotide polymorphism (SNP) 309 and increased development of tumors, such as hepatocellular carcinoma, has been subject to several studies. This is the first study on this association conducted in Brazil. Methods - 62 cases of cirrhotic patients with hepatocellular carcinoma surgically treated by partial hepatectomy (HPT) or by liver transplantation (LTX) from 2000 to 2009 at Santa Casa Hospital Complex, in the city of Porto Alegre, were retrospectively analyzed. Tumor samples from surgical specimen were collected and prepared for study in paraffin blocks. Results - Overall survival was 26.7 months in the HPT group and 62.4 months in the LTX group $(P<0.01)$. Overall tumor recurrence was $66.7 \%$ in the HPT group $(10 / 15)$ and $17 \%$ in the LTX group $(8 / 47)\left(X^{2}=13.602, P<0.01\right)$. Alpha-fetoprotein levels $>200 \mathrm{ng} / \mathrm{mL}$, microvascular invasion and histological grade were associated with tumor recurrence $(P<0.01)$. Recurrence rates in each surgical group and analysis of factors associated with tumor recurrence, when stratified for each genotypic pattern, were both not statistically significant. Conclusion - G/G genotype was not associated with tumor recurrence after surgical treatment and it did not show any correlation with other prognostic factors.
\end{abstract}

HEADINGS - Proto-oncogene proteins C-MDM2. Single-stranded conformational polymorphism. Hepatocellular carcinoma. Biological tumor markers

\section{INTRODUCTION}

With advancements in molecular epidemiology, the concept of individual susceptibility factors modulating environmental factors became the focus of various research efforts ${ }^{(20)}$. Discovery and incorporation of biomarker panels to cancer studies enabled the understanding of genetic variations and their interference in carcinogenesis ${ }^{(23)}$.

DNA (deoxyribonucleic acid) repair is a crucial mechanism in guaranteeing genome integrity ${ }^{(28)}$ and P53 protein plays an essential role in this process. Identified for the first time in 1979, P53 was later described as "guardian of the genome" for blocking inappropriate cellular proliferation and directing cells to apoptosis ${ }^{(3)}$. Other proteins were later recognized as p53 regulators, such as Murine Double Minute 2
(MDM2). This protein acts as a negative regulator by reducing P53 cellular activity and promoting its degradation ${ }^{(5,15)}$.

MDM2 T309G single nucleotide polymorphism (SNP) is the substitution of a thymine for a guanine in the 309 position of the MDM2 gene. Since the first publication regarding this polymorphism in $2004^{(4)}$, researchers have been trying to document the association between MDM2 T309G SNP and increased tumor formation. MDM2 hyperfunction in consequence of SNP309 would lead to a reduction in p53 levels and activity. MDM2-p53 interaction has already been targeted by several studies about cancer behavior $^{(2,11,19)}$.

Hepatocellular carcinoma (HCC) is a high incidence malignancy and it is responsible for high mortality rates all over the world ${ }^{(12)}$. The MDM2-p53

\footnotetext{
Declared conflict of interest of all authors: none Disclosure of funding: no funding received

${ }^{1}$ Programa de pós-graduação em Medicina, Hepatologia, Universidade Federal de Ciências da Saúde de Porto Alegre, Porto Alegre, RS, Brasil; ${ }^{2}$ Programa de graduação em Medicina, Universidade Federal de Ciências da Saúde de Porto Alegre, RS, Brasil; ${ }^{3}$ Departamento de Patologia, Universidade Federal do Rio Grande do Sul, Porto Alegre, RS, Brasil.

Correspondence: Uirá Fernandes Teixeira. Rua Professor Cristiano Fischer, 818, 802. Petrópolis - CEP: 91410-000 - Porto Alegre, RS. E-mail: uiraft@yahoo.com.br
} 
association is still uncertain considering this type of tumor. A number of risk factors and prognostic factors are known for this type of carcinoma, and surgical resection remains as a main treatment method ${ }^{(10,14,18)}$. However, correlations between genetic alterations, tumor recurrence and prognostic factors are not well established.

This is the first study conducted in Brazil to analyze the influence of Murine Double Minute 2 - T309G polymorphism on tumor recurrence in cirrhotic patients with HCC after standard surgical treatment. Associations between numerous genotypes and known prognostic factors, such as number of tumors, preoperative alpha-fetoprotein levels, tumor size, histological grade and microvascular invasion are also to be reported. The Institutional Ethics Committee approved the study under the report 350.488 in 07/17/2013.

\section{METHODS}

An observational and retrospective study was conducted. Cirrhotic patients who underwent surgery for hepatocellular carcinoma from 2000 to 2009 at Santa Casa Hospital Complex in Porto Alegre, South Brazil were selected. Tumor samples from surgical specimen (explanted liver or hepatic segment) were collected and prepared for study in paraffin blocks. All patients had histological confirmation of cirrhosis and hepatocellular carcinoma through anatomopathological study.

From 124 initial samples, 8 samples were discarded owing to insufficient material and 24 samples were rejected for excess of necrosis. From the remainder 92 samples, 11 samples were eliminated for failure in DNA extraction and 14 samples were excluded for failure in DNA amplification. From the final 67 samples, 62 subjects were selected, after the removal of 3 patients due to incomplete medical records and 2 patients due to death in relation to surgery.

The paraffin blocks were sliced in $4 \mu \mathrm{m}$ fragments. After preparation, we extracted DNA using Bioneer extraction kit (Bionner Corporation, EE.UU.), accordingly to manufacturer instructions. We evaluated DNA quantity and integrity by sample, using NanoDrop (NanoDrop Technologies, Wilmington, EUA). DNA from each sample was extracted, quantified and stored at $-20^{\circ} \mathrm{C}$.

Molecular identification of MDM2 T309G polymorphism was executed through polymerase chain reaction (PCR) technique. TaqMan essay and Step One Plus thermal cycler (Applied Biosystems, Foster City, CA) were used for this step. A pair of primers was employed to identify the DNA sequence that contained the polymorphism (Foward 5'CGGGAGTTCAGGGTAAAGGT 3'e Reverse:5' ACAGGCACCTGCGATCATC 3'). Two probes were employed, the first to identify the allele that enclosed the polymorphism and the second to identify the allele without the polymorphism (VIC-5'-CTCCCGCGCCGAAG-3' and FAM-5'TCCCGCGCCGCAG-3') (primers and probes from Applied Biosystems, Foster City, CA).

Patient-related data were collected in institutional medical records. The last measure of alpha-fetoprotein (AFP) levels before surgery was the one considered and it was stratified in categories due to the variability of values. Viral hepatitis infection was confirmed by specific serology. Number of tumors, size of the largest tumor, vascular invasion and histological grade were documented accordingly to anatomopathological study. Histological grade was classified as well-differentiated (1), moderately differentiated (2) and poorly differentiated (3). Tumor recurrence evaluation was defined based on standardized radiologic criteria (triphasic computed tomography or magnetic resonance imaging) or liver biopsy.

Statistical analysis was executed using PSPP 0.8 .4 software. Chisquare test was conducted considering a significance level of $5 \%$.

\section{RESULTS}

Table 1 presents the sample. Of 62 patients, 52 patients were male $(83.9 \%)$ and 10 patients were female $(16.1 \%)$.

TABLE 1. Characteristics of the sample and results of anatomopathological study

\begin{tabular}{|c|c|}
\hline Variables & $\mathrm{n}=62$ \\
\hline Age (years) & $65(50-84)$ \\
\hline $\begin{array}{l}\text { Sex, } \mathrm{n}^{\circ}(\%) \\
\text { Male } \\
\text { Female }\end{array}$ & $\begin{array}{l}52(83.9) \\
10(16.1)\end{array}$ \\
\hline $\begin{array}{l}\text { AFP, } \mathrm{ng} / \mathrm{mL}(\%) \\
\leq 50.0 \mathrm{ng} / \mathrm{mL} \\
50.1 \text { a } 200.0 \mathrm{ng} / \mathrm{mL} \\
>200.0 \mathrm{ng} / \mathrm{mL}\end{array}$ & $\begin{aligned} 42 & (67.7) \\
5 & (8.1) \\
15 & (24.2)\end{aligned}$ \\
\hline $\begin{array}{l}\text { Viral Hepatitis, } \mathrm{n}^{\circ}(\%) \\
\text { VHC } \\
\text { VHB } \\
\text { VHC + VHB }\end{array}$ & $\begin{array}{l}54(87.1) \\
2(3.2) \\
1(1.6)\end{array}$ \\
\hline $\begin{array}{l}\text { Number of nodules }(\%) \\
1 \\
2 \\
3 \\
\geq 4\end{array}$ & $\begin{array}{c}40(64.5) \\
14(22.6) \\
5(8.1) \\
3(4.8)\end{array}$ \\
\hline $\begin{array}{l}\text { Size of largest nodule } \\
\text { Up to } 3 \mathrm{~cm} \\
3.1 \text { a } 5 \mathrm{~cm} \\
>5 \mathrm{~cm}\end{array}$ & $\begin{array}{c}40(64.5) \\
18(29.0) \\
4(6.5)\end{array}$ \\
\hline $\begin{array}{l}\text { Surgery, } \mathrm{n}^{\circ}(\%) \\
\text { Partial hepatectomy } \\
\text { Liver transplantation }\end{array}$ & $\begin{array}{l}15(24.2) \\
47(75.8)\end{array}$ \\
\hline $\begin{array}{l}\text { Histological grade, } \mathrm{n}^{\circ}(\%) \\
\text { Well-differentiated (1) } \\
\text { Moderately differentiated (2) } \\
\text { Poorly differentiated (3) }\end{array}$ & $\begin{array}{l}10(16.1) \\
36(58.1) \\
16(25.8)\end{array}$ \\
\hline $\begin{array}{l}\text { Microvascular invasion, } \mathrm{n}^{\circ}(\%) \\
\text { Yes } \\
\text { No }\end{array}$ & $\begin{array}{l}22(35.5) \\
40(64.5)\end{array}$ \\
\hline $\begin{array}{l}\text { Genotype, } \mathrm{n}^{\circ}(\%) \\
\text { G/G } \\
\mathrm{T} / \mathrm{G} \\
\mathrm{T} / \mathrm{T}\end{array}$ & $\begin{array}{l}22(35.5) \\
17(27.4) \\
23(37.1)\end{array}$ \\
\hline
\end{tabular}


Mean age was 65 years (50-84 years). Hepatitis $C$ virus was present in $87.1 \%$ of patients. Stratification by AFP levels showed that $67.7 \%$ of patients presented values fewer than or equal to $50 \mathrm{ng} / \mathrm{mL}$. Single tumor was observed in $64.5 \%$ of patients. Size of the largest tumor was fewer than or equal to $3 \mathrm{~cm}$ in 40 patients $(65.4 \%) ; 22$ participants displayed genotype $\mathrm{G} / \mathrm{G}$, 17 participants displayed genotype $\mathrm{T} / \mathrm{G}$ and 23 the $\mathrm{T} / \mathrm{T}$ one.

Overall survival was 26.7 months in the HPT group and 62.4 months in the LTX group $(P<0.01)$. Global recurrence rate was $29 \%$ (18 patients - 10 patients from the hepatectomy group and 8 patients from the transplantation group). There was $66.7 \%$ of global recurrence in the HPT group (10/15) and $17 \%$ of global recurrence in the LTX group (8/47) $\left(\mathrm{X}^{2}=13.602, P<0.01\right)($ Figure 1$)$.

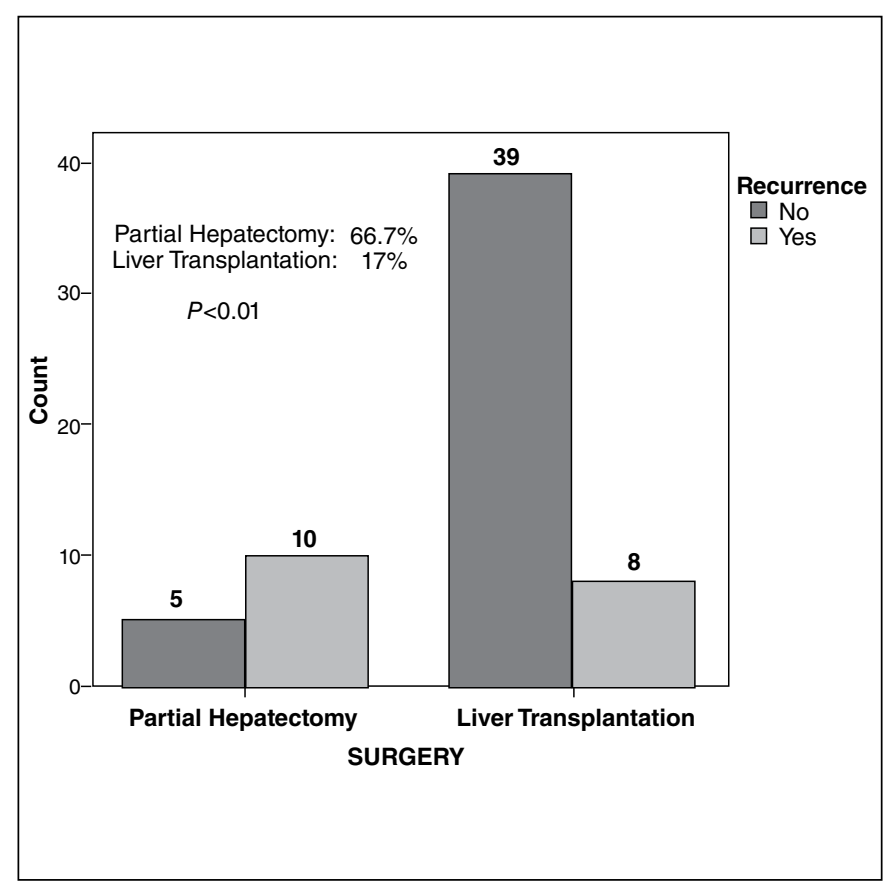

FIGURE 1. Tumor recurrence stratified by surgery

Regarding recurrence rate and preoperative AFP levels between surgical groups, in the LTX group (eight patients), $50 \%$ had AFP levels $>200 \mathrm{ng} / \mathrm{mL}, 37.5 \%$ levels $<50 \mathrm{ng} / \mathrm{mL}$ and $12.5 \%$ values between 50.1 and $200 \mathrm{ng} / \mathrm{mL}(P=0.042)$. In the HPT group (10 patients), $70 \%$ of patients had AFP levels $>200 \mathrm{ng} / \mathrm{mL}, 20 \%$ levels between 50.1 and $200 \mathrm{ng} / \mathrm{mL}$ and $10 \mathrm{had}<50 \mathrm{ng} / \mathrm{mL}(P<0.024)$.

Considering microvascular invasion, $83.3 \%$ of patients with recurrence presented it in anatomopathological study $(P<0.01)$. In the HPT group, $66.7 \%$ had microvascular invasion and from these, $80 \%$ presented recurrence $(P>0.05)$. In the LTX group, $25.5 \%$ of patients had microvascular invasion and from these, $58.3 \%$ presented recurrence $(P<0.01)$.

Regarding tumor differentiation, from the 18 patients with recurrence, $10(55.6 \%)$ presented poorly differentiated tumors, $6(33.3 \%)$ presented moderately differentiated tumors and $2(11.1 \%)$ well-differentiated tumors $(P=0.034)$.
In the analysis of groups by genotype, in the HPT group $50 \%$ of patients with recurrence presented $\mathrm{G} / \mathrm{G}$ genotype, $30 \%$ presented $\mathrm{T} / \mathrm{T}$ genotpe and $20 \%$ the $\mathrm{T} / \mathrm{G}$ genotype $(P=0.221)$. In the LTX group, $50 \%$ of patients with recurrence carried $\mathrm{G} / \mathrm{G}$ genotype, $37.5 \%$ the $\mathrm{T} / \mathrm{G}$ genotype and $12.5 \%$ the $\mathrm{T} / \mathrm{T}$ one $(P>0.05)$.

Study of prognostic factors related to hepatocellular carcinoma revealed that $45.5 \%$ of patients were G/G genotype, $31.8 \%$ were $\mathrm{T} / \mathrm{G}$ genotype and $22.7 \%$ the $\mathrm{T} / \mathrm{T}$ genotype among the 22 patients with microvascular invasion. In the group with AFP levels $>200 \mathrm{ng} / \mathrm{mL}, 40 \%$ of patients presented T/G genotype, $33.3 \%$ presented G/G genotype and $26.7 \%$ the T/T genotype $(P>0.05)$. Considering the 16 patients with poorly differentiated tumors, 43.8 were $\mathrm{G} / \mathrm{G}$ genotype, $37.4 \%$ were $\mathrm{T} / \mathrm{T}$ and $18.8 \%$ of patients were $\mathrm{T} / \mathrm{G}(P>0.05)$. For individuals with 1 tumor, distribution was $42.5 \%$ of patients with $\mathrm{T} / \mathrm{T}$ genotype, $27.5 \%$ with $\mathrm{T} / \mathrm{G}$ genotype and $30 \%$ with the G/G one. Finally, among patients with tumors up to $3 \mathrm{~cm}$, proportion to each genotype was $37.5 \%$ with $\mathrm{G} / \mathrm{G}$, $35 \%$ with $\mathrm{T} / \mathrm{G}$ and $25.5 \%$ of patients with $\mathrm{T} / \mathrm{T}$ genotype $(P>0.05)$ (Table 2).

TABLE 2. Distribution of prognostic factors for each genotype

\begin{tabular}{|c|c|c|c|c|}
\hline \multirow{2}{*}{ Prognostic factors } & \multicolumn{3}{|c|}{ Genotype } & \multirow{2}{*}{$P$ value } \\
\hline & TT & TG & GG & \\
\hline \multicolumn{5}{|l|}{ AFP, $\mathrm{ng} / \mathrm{mL}$} \\
\hline$\leq 50.0$ & 18 & 9 & 15 & \\
\hline 50.1 a 200.0 & 1 & 2 & 2 & \\
\hline$>200.0$ & 4 & 6 & 5 & $>0.05$ \\
\hline
\end{tabular}

Microvascular invasion

$$
\begin{aligned}
& \text { Yes } \\
& \text { No }
\end{aligned}
$$

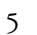

18

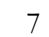

10

Histological grade

$\begin{array}{lcccc}\text { Well } & 4 & 2 & 4 & \\ \text { Moderately } & 13 & 12 & 11 & \\ & & & & >0.05\end{array}$

Number of nodules

$\begin{array}{lcccc}1 & 17 & 11 & 12 & \\ 2 & 2 & 5 & 7 & \\ 3 & 3 & 0 & 2 & \\ \geq 4 & 1 & 1 & 1 & >0.05 \\ \text { Size largest nodule } & & & & \\ \text { Up to } 3.0 \mathrm{~cm} & 11 & 14 & 15 & \\ 3.1 \text { a } 5.0 \mathrm{~cm} & 10 & 3 & 5 & >0.05 \\ >5.0 \mathrm{~cm} & 2 & 0 & 2 & \end{array}$




\section{DISCUSSION}

The identification of risk factors for prognosis in $\mathrm{HCC}$ after surgical treatment has been a constant aim of research. The recognition of genetic alterations and specific genotypes that may directly interfere in outcome and in factors known to be related to unfavorable results are of significant relevance.

Regarding type of surgery, hepatectomy was more closely related to tumor recurrence when compared with liver transplantation. Even though surgical resection offers a chance of cure, recurrence rates are high after surgery and cumulative recurrence incidence in 5 years varies from 40 to $70 \%$ in several studies ${ }^{(6)}$. In a study conducted in Santa Casa Hospital Complex in Porto Alegre in 2008, Silva et al.(22) analyzed cirrhotic patients with hepatocellular carcinoma after surgical resection and observed a mean survival of 33.5 months; $61.9 \%$ of survival in 1 year, $16.67 \%$ in 3 years and $11.11 \%$ in 5 years. A tumor recurrence rate of $68.4 \%$ was obtained, mostly in the first year after surgery. A mean survival of 26.7 months and a recurrence rate of $66.7 \%$ were found in our study.

Other factors related to tumor recurrence in our series were preoperative AFP levels $>200 \mathrm{ng} / \mathrm{mL}$, poorly differentiated histological grade and microvascular invasion. These results match the current literature, which states that tumors size larger than $5 \mathrm{~cm}$, less differentiation, elevated AFP levels and vascular invasion are related to poor prognosis ${ }^{(6)}$. Park et al. ${ }^{(17)}$ reported similar parameters in a study conducted in Korea, whereas AFP levels $>400 \mathrm{ng} / \mathrm{mL}, \mathrm{HCC}>5 \mathrm{~cm}$, multiple tumors and vascular invasion were related to less favorable outcomes. On the other hand, Shindoh et al. ${ }^{(21)}$ observed that long-term survival was not affected by microvascular invasion among patients presenting small HCC tumors (fewer than $2 \mathrm{~cm}$ ); the opposite happened in cases with tumors larger than $2 \mathrm{~cm}$.

Divergence in our study was observed considering number of tumors and size of the largest tumor: both were not associated with recurrence - in opposite to what was revealed by the studies listed in the last paragraph. A cause for this abnormality could be the small sample in our study. In literature, the number of tumors is conspicuously a poor prognosis factor after surgical treatment and it is associated to high recurrence rates and a low life expectancy ${ }^{(25)}$. Also, in our series most patients had a single tumor, smaller than $3 \mathrm{~cm}$, making the comparison between groups more difficult to proceed with. In 2004, Chen et al. ${ }^{(6)}$ demonstrated an association between multiple initial lesions, short recurrence interval and adverse outcomes.

Regarding the T309G polymorphism, current literature shows conflicting results. In the last few years, various researchers have been trying to evaluate association between SNP T309G and hepatocellular carcinoma. In 2007, Leu et al. ${ }^{(16)}$ analyzed the MDM2-SNP-309 genotype of 58 patients with $\mathrm{HCC}$ and hepatitis $\mathrm{B} / \mathrm{C}$ in Taiwan, in comparison with healthy controls. A similar proportion of the homozygous genotype MDM2-SNP $309(\mathrm{G} / \mathrm{G})$ was found in cases and controls. No difference in prevalence of $\mathrm{G} / \mathrm{G}$ and $\mathrm{T} / \mathrm{T}$ genotype was found among patients presenting HCC. On the other hand, between 2001 and 2003, Dharel et al. ${ }^{(7)}$ studied 435 patients with hepatitis $\mathrm{C}-187$ patients with $\mathrm{HCC}$ and 248 patients without HCC - and obtained DNA samples from 48 healthy controls to estimate genetic distribution of SNP309 in Japan. G/G genotype proportion in patients with HCC was significantly higher than in healthy individuals. G/G genotype was independently associated to HCC when compared with $\mathrm{T} / \mathrm{T}$ genotype.

In 2011, Di Vuolo et al ${ }^{(8)}$ analyzed the genotypic distribution of 61 patients with HCC and viral hepatitis in comparison with 122 healthy controls. Frequency of MDM2-SNP309 $\mathrm{G} / \mathrm{G}$ and $\mathrm{T} / \mathrm{G}$ genotypes was significantly higher in patients presenting HCC. Furthermore, when the MDM2-SNP309 $\mathrm{T} / \mathrm{T}$ group was used as a reference, $\mathrm{G} / \mathrm{G}$ and $\mathrm{T} / \mathrm{G}$ genotypes were associated with a higher risk of HCC.

The potential role of the MDM2-SNP polymorphism in HCC development was analyzed in other studies. MDM2-SNP allele was associated with a higher risk of developing HCC in Korean patients with chronic hepatitis $\mathrm{B}^{(27)}$, Moroccan patients with viral hepatitis ${ }^{(9)}$ and Turkish patients ${ }^{(1)}$. In 2011, Jin et al. ${ }^{(13)}$ published a meta-analysis of these studies, including 738 cases and 1062 controls, in order to evaluate the association of MDM2-SNP-309 G allele with HCC. The grouped odds ratio was 1.57 (CI 95\%; 1.36-1.80) for $\mathrm{G}$ allele when compared with $\mathrm{T}$, indicating that this SNP may be used as a predictive molecular marker for HCC screening in high-risk populations.

Tang et al. ${ }^{(24)}$, in a recent meta-analysis including 10 studies -2.243 cases and 3.471 controls - also detected an association between $\mathrm{T} 309 \mathrm{G}$ polymorphism and a higher risk of hepatocellular carcinoma in all three genetic models $(\mathrm{G}$ vs. T: $\mathrm{OR}=1.39,95 \%$ CI $1.17-1.64$; GG vs TT: $\mathrm{OR}=1.87$, $95 \%$ CI $1.34-2.62, P<0.001 ; \mathrm{GG} / \mathrm{GT}$ vs TT: $\mathrm{OR}=1.61,95 \%$ CI 1.24-2.08, $P<0.001)$.

Concerning the association between SNP309 and prognostic factors related to HCC after surgical treatment, current literature is scarce. A single study conducted by Yang et al. in $2003^{(26)}$ contemplated this association and noticed patients presenting $\mathrm{G} / \mathrm{G}$ genotype had disease-free survival and global survival similar to other genotypes.

In our study, $50 \%$ of patients with recurrence in each group were $\mathrm{G} / \mathrm{G}$ genotype carriers. This difference, even though epidemiologically expressive, was not statistically significant, possibly because of the small sample. Regarding prognostic factors, most patients with microvascular invasion and poorly differentiated tumors presented G/G genotype (45.5\% and $43.8 \%$, respectively), a result that express a tendency, despite not statistically significant. Analysis of microvascular invasion revealed $\mathrm{T} / \mathrm{T}$ genotype was present in most patients $(45 \%)$ who did not present this feature - reinforcing once more the possible influence of the mutation to the occurrence of invasion. Genotypic distribution of the other features evaluated varied and did not follow a pattern according to genotype.

This is the first study concerning T309G in Brazil and evaluating the polymorphism association with hepatocel- 
lular carcinoma and its recurrence after surgical treatment. As retrospective study, it is vulnerable to bias inherent to this design. As the variables studied were laboratorial measures and pathology results, data collection was facilitated. Working with patients from a single center was another limiting factor, as was the reduced sample.

\section{Authors' contributions}

Data collection: Teixeira UF, Marchry MC, Izaguirre AGC. Search literature: Teixeira UF, Izaguirre AGC. Data analysis: Marchry MC, Cerski CT, Brandão ABM, Fontes PRO. Manuscript writing: Teixeira UF, Brandão ABM, Fontes PRO.

Teixeira UF, Izaguirre AGC, Marchry MC, Cerski CT, Brandão ABM, Fontes PRO. Associação entre o polimorfismo T309G - murine double minute 2 e a recorrência do carcinoma hepatocelular após o tratamento cirúrgico. Arq Gastroenterol. 2015,52(4):xxx.

RESUMO - Contexto - A descoberta e incorporação de painéis de biomarcadores aos estudos do câncer permitiram o conhecimento de variações genéticas e sua interferência no processo de carcinogênese. A possibilidade de associação do polimorfismo de nucleotídeo simples T309G do gene MDM2 com o aumento da formação de tumores, dentre eles o hepatocarcinoma, tem sido alvo de diversos estudos. Objetivo - Analisar a influência do polimorfismo T309G do gene MDM2 na recidiva tumoral de pacientes cirróticos com hepatocarcinoma submetidos a tratamento cirúrgico. Métodos - Foram analisados retrospectivamente pacientes cirróticos com carcinoma hepatocelular submetidos a tratamento cirúrgico (hepatectomia parcial ou transplante hepático) no período de 2000 a 2009, na Santa Casa Hospital Complex in Porto Alegre, South Brazil. Foram coletadas amostras de fragmentos tumorais da peça operatória (fígado explantado ou segmento hepático), as quais foram preparadas para estudo em bloco parafinado. Resultados - A sobrevida global foi de 26,7 meses para o grupo hepatectomias e 62,4 meses para o grupo transplante hepático $(P<0,01)$, havendo $66,7 \%$ de recidiva global no grupo hepatectomias (10/15), e 17\% no grupo transplante hepático $(8 / 47)\left(\mathrm{X}^{2}=13,602, P<0.01\right)$. Níveis de AFP $>200$ ng/ $\mathrm{mL}$ correlacionaram-se com a recidiva tumoral em ambos os subgrupos cirúrgicos. Observou-se que $83,3 \%$ dos pacientes com recidiva também apresentaram invasão microvascular ao exame anátomo-patológico $(P<0,01)$. Não houve significância estatística quando a recidiva neoplásica foi avaliada para os diferentes genótipos e analisada para cada subgrupo cirúrgico. A análise dos fatores prognósticos relacionados à recidiva do hepatocarcinoma, quando estratificada para cada padrão genotípico, também não se mostrou significante. Conclusão - O nosso estudo revelou que o genótipo G/G não esteve associado à recidiva tumoral após o tratamento cirúrgico, seja nas hepatectomias parciais ou transplante hepático. Além disso, a presença desse genótipo não mostrou correlação com os fatores prognósticos estudados.

DESCRITORES - Proteínas proto-oncogênicas C-MDM2. Polimorfismo conformacional de fita simples. Carcinoma hepatocelular. Marcadores biológicos de tumor. 


\section{REFERENCES}

1. Akkiz H, Sumbul AT, Bayram S, Bekar A, Akgollu E. MDM2 promoter polymorphism is associated with increased susceptibility to hepatocellular carcinoma in Turkish population. Cancer Epidemiol. 2010;34(4):448-52.

2. Alhopuro P, Ylisaukko-Oja SK, Koskinen WJ, Bono P, Arola J, Jarvinen HJ, et al. The MDM2 promoter polymorphism SNP309T-G and the risk of uterine leiomyosarcoma, colorectal cancer and squamous cell carcinoma of the head and neck. J Med Genet. 2005;42(9):694-8.

3. Bai L, Zhu WG. P53: Structure, function and therapeutic applications. J Cancer Mol. 2006;2(4):141-53.

4. Bond GL, Hu W, Bond EE, Robins H, Lutzker SG, Arva NC, et al. A single nucleotide polymorphism in the MDM2 promoter attenuates the $\mathrm{p} 53$ tumor suppressor pathway and accelerates tumor formation in humans. Cell. 2004;119(5):591-602.

5. Cahilly-Snyder L, Yang-Feng T, Francke U, George DL. Molecular analysis and chromosomal mapping of amplified genes isolated from a transformed mouse 3T3 cell line. Somat Cell Mol Genet 1987;13(3):235-44.

6. Chen WT, Chau GY, Lui WY, Tsay SH, King KL, Loong CC, et al. Recurrent hepatocellular carcinoma after hepatic resection: prognostic factors and long-term outcome. Eur J Surg Oncol. 2004;30(4):414-20.

7. Dharel N, Kato N, Muroyama R, Moriyama M, Shao RX, Kawabe T, et al. MDM2 promoter SNP309 is associated with the risk of hepatocelular carcinoma in patients with chronic hepatitis C. Clin Cancer Res 2006;12:4867-4871.

8. Di Vuolo V, Buonaguro L, Izzo F, Losito S, Botti B, Buonaguro FM, et al. TP53 and MDM2 gene polymorphisms and risk of hepatocellular carcinoma among Italian patients. Infect Agent Cancer. 2011;6:13.

9. Ezzikouri S, El Feydi AE, Afifi R, El Kihal L, Benazzouz M, Hassar M, et al. MDM2 SNP309T $>$ G polymorphism and risk of hepatocellular carcinoma: a case-control analysis in a Moroccan population. Cancer Detect Prev. 2009;32(5-6):380-5.

10. Fan ST, Lo CM, Liu CL, Lam CM, Yuen WK, Yeung C, et al. Hepatectomy for hepatocellular carcinoma: toward zero hospital deaths. Ann Surg. 1999;229(3):322-30

11. Hu Z, Jin G, Wang L, Chen F, Wang X, Shen H. MDM2 promoter polymorphism SNP309 contributes to tumor susceptibility: evidence from 21 case-control studies. Cancer Epidemiol Biomarkers Prev. 2007;16(12):2717-23.

12. Jemal A, Bray F, Center MM, Ferlay J, Ward E, Forman D. Global cancer statistics Ca Cancer J Clin. 2011;61(2):69-90.

13. Jin F, Xiong WJ, Jing JC, Feng Z, Qu LS, Shen XZ. Evaluation of the association studies of single nucleotide polymorphisms and hepatocellular carcinoma: a systematic review. J Cancer Res Clin Oncol. 2011;137(7):1095-104.
14. Khan AS, Fowler KJ, Chapman WC. Current surgical treatment strategies for hepatocellular carcinoma in North America. World J Gastroenterol. 2014;20(41):15007-17.

15. Kubbutat MH, Jones SN, Vousden KH. Regulation of p53 stability by MDM2 Nature. 1997;387:299-303

16. Leu J-D, Lin I-F, Sun Y-F, Chen S-M, Liu C-C, Lee Y-J. Association between MDM2-SNP309 and hepatocellular carcinoma in Taiwanese population. World J Gastroenterol. 2009;15(44):5592-97.

17. Park SK, Jung YK, Chung DH, Kim KK, Park YH, Lee JN, et al. Factors influencing hepatocellular carcinoma prognosis after hepatectomy: a single-center experience. Korean J Intern Med. 2013;28(4):428-38

18. Pawlik TM, Poon RT, Abdalla EK, Zorzi D, Ikai I, Curley SA, et al. Critical appraisal of the clinical and pathologic predictors of survival after resection of large hepatocellular carcinoma. Arch Surg. 2005;140(5):450-7.

19. Peng Q, Mo C, Qin A, Lao X, Chen Z, Sui J, et al. MDM2 SNP309 polymorphism contributes to endometrial cancer susceptibility: evidence from a meta-analysis. J Exp Clin Cancer Res. 2013;32(85):1-9.

20. Perera FP, Weinstein IB. Molecular epidemiology: recent advances and future directions. Carcinogenesis. 2000;21(3):517-24.

21. Shindoh J, Andreou A, Aloia TA, Zimmitti G, Lauwers GY, Laurent A, et al. Microvascular invasion does not predict long-term survival in hepatocellular carcinoma up to $2 \mathrm{~cm}$ : reappraisal of the staging system for solitary tumors. Ann Surg Oncol. 2013;20(4):1-14.

22. Silva M, Mattos AA, Fontes PRO, Waechter FL, Pereira-Lima L. Evaluation of hepatic resection for hepatocellular carcinoma on cirrhotic livers. Arq Gastroenterol. 2008;45(2):99-105.

23. 2Spitz MR, Bondy ML. The evolving discipline of molecular epidemiology of cancer. Carcinogenesis. 2010;31(1):127-34

24. Tang T, Song X, Yang Z, Huang L, Wang W, Tan H. Association between murine double minute $2 \mathrm{~T} 309 \mathrm{G}$ polymorphism and risk of liver cancer. Tumor Biol. 2014;35:11353-7.

25. Tsai TJ, Chau GY, Lui WY, Tsay SH, King KL, Loong CC, et al. Clinical significance of microscopic tumour venous invasion in patients with resectable hepatocellular carcinoma. Surgery. 2000;127:603-8.

26. Yang Y, Xia T, Li N, Zhang J, Yang Y, Cong W, et al. Combined effects of p53 and MDM2 polymorphisms on susceptibility and surgical prognosis in hepatitis $\mathrm{B}$ virus-related hepatocellular carcinoma. Protein Cell. 2013;4(1):71-81.

27. Yoon YJ, Chang HY, Ahn SH, Kim JK, Park YK, Kang DR, et al. MDM2 and p53 polymorphisms are associated with the development of hepatocellular carcinoma in patients with chronic hepatitis B virus infection. Carcinogenesis. 2008;29:1192-6.

28. Zaridze DG. Molecular epidemiology of cancer. Biochemistry. 2008;73(5):532-42 